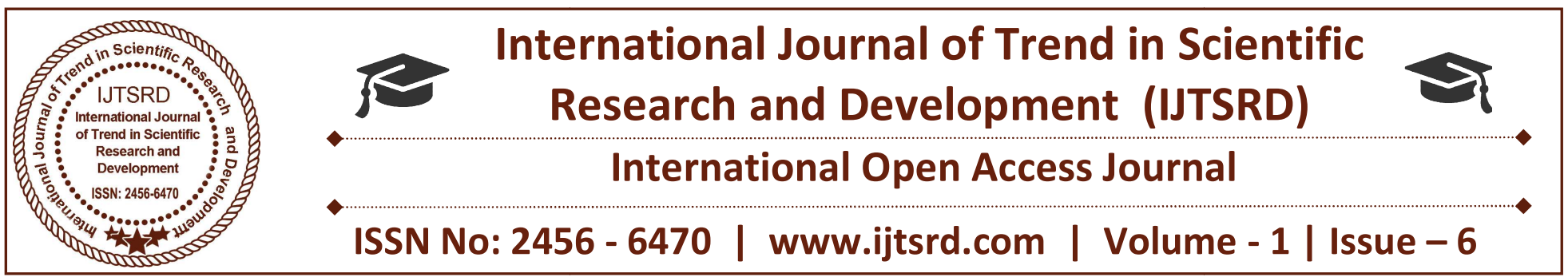

\title{
Ladies Coupe: A Feminist Study
}

\author{
Gh Mohd Mir \\ Research Scholar, Jiwaji \\ University, Gwalior, MP
}

\author{
Javaid Ahmad Ganaie \\ Research Scholar, Jiwaji \\ University, Gwalior, MP
}

\author{
Hasina Jabeen \\ Research Scholar, Jiwaji \\ University, Gwalior, MP
}

\section{ABSTRACT}

Feminism is a struggle for equality of women or an effort to make women equal to men. It is seen as the struggle against all forms of patriarchal and sexist aggression, such as oppositional definition presents, Feminism as the necessary resistance to the patriarchal power, logically then it is a theory of imagination. The universal idea of feminism believes that all men and women are equal and deserve equality in all opportunities, treatment, respect, economic rights, and social rights. Overall, feminists are the people who try to admit that there is a social inequality based on gender and want to stop it. Feminists comment that in most cultures through history men have received more opportunities than women. The purpose of this paper is to find a feminist aspect of Anita Nair's novel "Ladies coupe". The novelist explores that the women can live a happy life without a man. She can make a decision of her life. Ladies Coupe is a story of six women who are in search of autonomy and perseverance. As a woman novelist, Anita Nair depicts the problems of Indian women and probes into their psyche. The novel also deals with the transformation of the six women in the patriarchal society. The protagonist of the novel Akhila breaks out of the traditions of Indian society which chain her. Not only Akhila but also Prabha Devi, Janaki, Sheela, Margaret, and Marikolanthu emerge as independent personalities. The central character of "Ladies Coupe" has never been allowed to live her own life always the daughter, the sister, the aunt, the provider until the day she gets herself a oneway train ticket to the seaside town of Kanyakumari. In the train, she meets other five fellow travellers. In the interaction Akhila begins to seek answers to her questions those questions were haunting her all her life; can a woman stay single, and be happy or does she need a man to complete life.

Keywords: quest for Independence, equality, relationship, and self-identity

\section{Introduction}

"Ladies Coupe" is the great success of Anita Nair. She has narrated a story of Akhila and other five women. While the interaction of all six women who travel in the same women's compartment to kanyakumari. We find that they all are subjected to gender discrimination. They search for independence and self-identity in a male dominated society. The novel raises the questions whether the role of an Indian woman as a representative of other women, living under oppressive patriarchal systems in relation to cultural resistance, should be restricted only to their roles as wives and mothers. In such a world, woman's role is limited to reproduction regardless of her own desires and needs. So, in this paper researcher tries to show how the novelist projects the feminism in 'Ladies Coupe'.

\section{About Author}

Anita Nair is the living writer of this century is an Indian English writer. She was born in 1966 in Shornur in Palakkad district of Kerala.She lives in Bangalore with her husband, Harish and a son. She is a creative artist bestowed with unique talent and scholarly panorama. She is regarded as one of the leading novelists in Indian English Literature. In her 
works, Anita Nair mainly focuses on the real human condition on the earth. At the same time, she is artful in interweaving her stories in the Indian scenario, unique in presenting her conceptions and innovative in sharing the experiences of language. Exhibiting an individualistic flair in her writing style, Anita Nair's novels display an awe-inspiring depth in her narration, and the main thrust of her novels is the confrontation between the self-actualization and family responsibilities of the individuals. Almost all her novels are surrounded in Indian culture and the characters and settings are inherently Indian. Her stories may be said to be ideological as well as practical, based on the structure of Indian middleclass families. In this context, she displays a sharp mind and observation skill with which she details stories depicting the enigma of Indian women, in an easy manner.

\section{Akhila's Quest for Independence, Equality, Relationship, and self-identity}

Anita Nair stresseson men and women relations, marriage and divorce, social and cultural, and psychological issues in the novel 'Ladies Coupe'. In "Ladies Coupe", she deals with the concept of patriarchy and signifies inequality in relationships. Her novel raises questions about the role of women in contemporary postcolonial India. Her India suffers from a system of sex-role stereotyping and oppression of woman that exist under patriarchal social organization.

The woman characters in the novel "Ladies Coupe" seems to be the personification of new women who have been trying to throw off the burden of inhibitions they have carried for ages. They go through the gruelling experiences of domestic oppression at the hands of the repressive forces of society but finally, they revolted against the oppression and resolved to discover them and establish them in society.

Ladies Coupe tells the life stories of six women travelling in the ladies compartment, each of them unfolding their life to Akhila, the protagonist; she is travelling to find out what she really needs in life. Akhila is a scapegoat for her family, as she has taken all the responsibility of her mother and siblings when her father died. Even though she is an income generating source, most of the time she is not receiving social independence. Aged forty-five and the background demanding her to be a spinster, she feels lost without having a companion and getting exploited by her sister. The novel roams through the memories of Akhila, interconnected by the storytelling of fellow passengers and their empathy towards each other. The ladies compartment becomes a platform for them to express themselves and support each other. A bond of sisterhood is suddenly created among the women from different caste, class and age. The story of Marikolanthu, a Dalit woman, remains unique and reveals the multiple layers of exploitation she has faced in her life by being a woman, minor, Dalit, and poor. Akhila finally decides to resume her old romantic relationship and take a bold stand in her life. After listening to the stories of fellow travellers, Akhila came to know that all women are suppressed. Women, in general, want to end this suppression and wish to live a free life. Akhila somehow feels that she has lost her own identity and she is in search of selfidentity. Akhilarealises that we need to eliminate the gender discrimination. Women should be given an opportunity to live their lives as men live but she lived her life as she was told. She breaks the fear and goes to Kanyakumari. She leaves her home and reaches to the railway station. She says;

"I am here, her heart galloped. A tiny
foam-edged wave of pure emotion rushed
through her. She felt her lips stretch into a
smile. I am part of a ripple that will
escape this city tonight. I will board a
train and allow it to lead me into the
horizon I will not recognize."

\section{The Treatment of Feminism in Anita Nair's Novel 'Ladies Coupe'}

Feminism is, certainly, a serious effort to examine, understand and elucidate how and why feminity is or the feminine sensibility is dissimilar to masculinity or the masculine experience. It brings into perspective the points of dissimilarities that characterize the 'feminine identity' or 'feminine psyche' or 'feminity' of a woman. It can be studied by taking into account the psychosomatic, social and cultural construction of feminityvis-a-vis masculinity.'

The male writers have mostly seen women as mediocre and frail. Gendering and some sort of misogyny are evident in the texts written by men. They treat men as 'grander sex' or the 'stronger sex' while women are treated as 'inferior sex' or the 'weaker sex'. Men are supposed as logical, rational and objective, and, women are supposed as emotional, 
inconsistent, instinctive, subjective and lacking selfconfidence.

In "Ladies Coupe", Anita Nair deals with the concept of patriarchy and shows inequality in relationships. Her novel raises questions about the role of women in contemporary postcolonial India. The India suffers from a system of sex-role stereotyping and oppression of woman that exist under patriarchal social organization. The characters of 'Ladies Coupe' show, the gender discrimination and depicts how women are asked to turn down their will before the will of their husband. The aunts of Janaki say to her;

"He is your husband and you must accept whatever he does, 'Janaki's aunts had whispered as they led her to the bedroom adorned with Jasmine and scented with incense sticks......." (25)

\section{Conclusion}

Anita Nair uses relationship to guide the moral evaluation of the characters. Thus the journey of Akhila for search of relationship, independence, and self-identity, no doubt her stubborn will and undefeatable spirit obliges her to carry on her life in a resuscitate way. The novelist wisely depicts the shades of pain, love, anger, frustration and, discrimination in 'Ladies Coupe'. This novel is about modern Indian society, about the consciousness of the battles between one's ambitions, visions in life, the threads of intolerance, anger, violence and the survival of one's traditional values and ideas still in the present conditions. Anita Nair is possibly the only Indian woman novelist who has made a daring effort to give voice to the suppressed women and to work for welfare of women in a patriarchal world. It is a novel which incites the readers thought and moves them deeply and quietly.

\section{Reference}

1) Nair, Anita. Ladies Coupe: Pegiun Books. India, 2001.

2) Nair, Anita. The Better Man: Pengiun. India, 1999.

3) Nair, Anita. Chain Of Custody: Harper Collins Publishers, 2016.

4) Boehmer, Elleke. Colonial and Postcolonial Literature: Oxford University Press, 1995. 